\title{
A Study on Guidance and Incentive Measures for Undergraduate Entrepreneurship
}

\author{
Junjie Zhao' ${ }^{1}$ Xiaofeng Zhao ${ }^{2}$ \\ ${ }^{1}$ School of Business Administration, Anhui University of Finance and Economics, Bengbu, China \\ ${ }^{2}$ Library and Information Center, Anhui University of Finance and Economics, Bengbu, China \\ Email: 14535789@qq.com
}

How to cite this paper: Zhao, J.J. and Zhao, X.F. (2021) A Study on Guidance and Incentive Measures for Undergraduate Entrepreneurship. Open Access Library Journal, 8: e7422

https://doi.org/10.4236/oalib.1107422

Received: April 4, 2021

Accepted: May 15, 2021

Published: May 18, 2021

Copyright (C) 2021 by author(s) and Open Access Library Inc.

This work is licensed under the Creative

Commons Attribution International

License (CC BY 4.0).

http://creativecommons.org/licenses/by/4.0/

(c) (i) Open Access

\begin{abstract}
To encourage college students to start their own businesses, entrepreneurship education must go first. In the entrepreneurship education of college students, we should first understand the motivation of college students to start their own businesses and the reasons why they do not want to start their own businesses, and then give targeted guidance and incentives. By classifying and summarizing the questionnaire survey data, this paper summarizes the main reasons why college students do not want to start their own businesses, as well as the main motivation for college students to start their own businesses, and carries out in-depth analysis, and finally gives targeted guidance and incentive measures for college students to start their own businesses.
\end{abstract}

\section{Subject Areas}

Business and Economics Education

\section{Keywords}

Undergraduate Entrepreneurship, Guide, Incentives, Measures

\section{Introduction}

Since the expansion of university enrollment, China's higher education has gradually entered the stage of "popularization" [1]. Now the number of new jobs is lower than the number of college graduates every year, increasing employment pressure, this year there will be 8.74 million college graduates in China. At the same time, college student's entrepreneurship is an urgent need to implement the national innovation-driven development strategy, but the degree of innovation and entrepreneurship of Chinese college students is low, and there are still deviations in college students' understanding of the value of entrepreneurship 
[2]. At present, experts and scholars at home and abroad have carried out quite a lot of researches on college students' entrepreneurship, but most of them focus on entrepreneurship teaching methods, entrepreneurship subject system construction, entrepreneurship support policies and other aspects, while there are few researches on entrepreneurship guidance and incentive mechanism. A total of 46,542 results were found by searching the CNKI with the keyword "College Students Entrepreneurship", and the main topics ranked in the first place were as follows: College students' entrepreneurship (7295 items), entrepreneurship education (5,960 items), innovation and entrepreneurship education (3885 items), innovation and entrepreneurship education (3438 items), innovation and entrepreneurship education (2609 items), innovation and entrepreneurship education (2146 items), innovation and entrepreneurship education (1784 items), etc. To encourage college students to start their own businesses, entrepreneurship education must come first [3]. We believe that in the entrepreneurship education for college students, we should first understand the motivation of college students to start their own businesses and the reasons why they do not want to start their own businesses, and then give targeted guidance and incentives. Starting from the survey data, this paper analyzes the problems of college students' guidance and incentive mechanism, and explores the reasonable way of college students' entrepreneurial guidance and the effective and feasible incentive mechanism.

\section{Questionnaire Data}

\subsection{Samples and Data Collection}

In this survey, the students in two universities are the research objects. The method of combining offline and online is adopted. The offline method of printing questionnaires and filling in random survey is adopted. Use the questionnaire star tool online, distribute the questionnaire in QQ group and WeChat group and collect it. Before the actual survey, we conducted a preliminary survey on some college students, designed the options, and finally formed a formal questionnaire. In order to avoid the influence of others' opinions on the questionnaire answers, this paper is filled in anonymously to ensure the confidentiality of the questionnaire and the authenticity of the content. A total of 5000 questionnaires were sent out, and 4339 valid questionnaires were collected statistically. The effective recovery rate of the questionnaire was $86.8 \%$. The first part of the questionnaire involves the personal information of college students. The second part and the third part are two options to fill in, that is, those who do not want to start a business fill in the second part, those who have the intention or have started a business choose to fill in the third part. The second part is the investigation of the reasons for not wanting to start a business. The questionnaire lists some main opinions given by students in advance, and students are allowed to fill in the opinions not given in the questionnaire. Multiple choices are allowed in this part. The third part is the survey of entrepreneurial motivation. The questionnaire also lists the main opinions given by students in advance. At the same 
time, students are allowed to fill in the opinions not given in the questionnaire. Finally, according to the survey statistical results, I interviewed some of the students according to different types to understand the specific ideas of choosing the corresponding options in detail, and then sorted out and summarized.

\subsection{Survey Results}

Among the subjects surveyed, the proportion of men and women was close, and the age distribution ranged from 19 to 24 years old. There were 35 different majors involved, 57.2 of which were science and technology, and $42.8 \%$ of which were literature and history. 2710 people, or $62.5 \%$, chose not to start a business; 1629 people, accounting for $37.5 \%$, chose to start a business or were starting a business. There are many reasons for not wanting to start a business, such as lack of ability, lack of resources, fear of economic loss, lack of guidance from teachers, etc. In terms of entrepreneurial motivation, opinions are concentrated, mainly to gain profits, increase life experience, interest, experience and try. Specific survey results are shown in Table 1 and Table 2.

\section{Analysis of the Main Motivation of College Students to Start Their Own Businesses}

\subsection{Earning Revenue}

Although college students have been adults, but are still a student, no income, tuition, living expenses or rely on parents. This part of the expenses for some families is not a small burden, especially the rural families, so many students want to learn knowledge through their own efforts, but also through their own efforts, to get some income, to reduce the burden of the family. Of course, there are also

Table 1. Reasons for not starting a business.

\begin{tabular}{ccccccccc}
\hline Reason & $\begin{array}{c}\text { lack of } \\
\text { ability }\end{array}$ & $\begin{array}{c}\text { lack of } \\
\text { resources }\end{array}$ & $\begin{array}{c}\text { worry about } \\
\text { financial } \\
\text { loss }\end{array}$ & $\begin{array}{c}\text { lack of } \\
\text { teacher } \\
\text { guidance }\end{array}$ & $\begin{array}{c}\text { lack of } \\
\text { interest }\end{array}$ & $\begin{array}{c}\text { lack of } \\
\text { time, } \\
\text { energy }\end{array}$ & $\begin{array}{c}\text { delay } \\
\text { in }\end{array}$ & etc \\
\hline $\begin{array}{c}\text { Number of } \\
\text { people }\end{array}$ & 790 & 729 & 591 & 279 & 101 & 93 & 67 & 60 \\
\begin{tabular}{c} 
Percentage \\
\hline
\end{tabular} & $29.2 \%$ & $26.9 \%$ & $21.8 \%$ & 10.3 & $3.7 \%$ & $3.4 \%$ & $2.5 \%$ & $2.2 \%$ \\
\hline
\end{tabular}

The total number of people is 2711 . Other reasons in the table include family unsupport, physical health status, etc.

Table 2. And entrepreneurial motivation.

\begin{tabular}{cccccc}
\hline Motivation & gain gains & $\begin{array}{c}\text { increase life } \\
\text { experiences }\end{array}$ & $\begin{array}{c}\text { challenge } \\
\text { yourself }\end{array}$ & $\begin{array}{c}\text { be interested in, } \\
\text { experience to try } \\
\text { something }\end{array}$ & etc \\
\hline Number of people & 649 & 398 & 321 & 252 & 9 \\
Percentage & $39.8 \%$ & $24.4 \%$ & $19.7 \%$ & $15.5 \%$ & $0.6 \%$ \\
\hline
\end{tabular}

The total number of people is 1629 , and the number of people who choose other motives is relatively small, mainly to participate in the competition. 
some students just to earn some pocket money for their own use. In addition, you can experience the sense of accomplishment of getting paid by earning an income through starting your own business.

\subsection{Increase Life Experience}

Entrepreneurship, whether successful or not, will add to one's life experience, and this experience can be very deep and important. The cost of starting a business while you are a student is much lower than the cost of going to work and starting a business after graduation. The process of entrepreneurial experience plays an important role in personal growth, such as how to overcome setbacks, experience the hardships of entrepreneurship, and temper the spirit of hardship and so on. This role is sometimes difficult to replace by other courses or training. Life needs and is necessary to go through some ups and downs and failures, because after you go through these setbacks, you will find that life is not as smooth and beautiful as ordinary people think, and only through these, can your potential ability be stimulated in difficulties [4].

\subsection{Challenge Yourself and Try to Experience}

College students are full of passion and energy. They dare to challenge themselves and try new things. Try, is a sill of life. Without trying, it means that there is no source of ideas. It is by trying that one is forced to think, to be wise, to practice, and to discover. It is the painful experience of trying that makes people taste the joy of success and the taste of happiness [5]. By constantly challenging yourself, you can grow up quickly and enhance your ability to face and solve problems. By challenging yourself, you can discover your own weaknesses and shortcomings, and at the same time, you can discover your own strengths. Life is to face all kinds of challenges, from the beginning of the student should learn how to face, and entrepreneurship is one of the best experiences to challenge yourself.

\section{Analysis of the Main Reasons Why College Students do not Want to Start Their Own Businesses}

\subsection{Worry about Lack of Ability}

The Report on the Current Situation of Youth Entrepreneurship in China points out that the lack of entrepreneurial ability is one of the main difficulties faced by youth entrepreneurship. Many young people have successfully set up enterprises, but they are not able to develop and expand. In particular, they lack market awareness and scientific management methods, and they have common shortcomings in enterprise management, $\mathrm{R} \& \mathrm{D}$ and innovation, marketing and promotion, financing skills and other abilities [6]. Starting a business is a very complex job, which requires a high level of personal ability. Most college students have never been exposed to the society, so they lack confidence in their own abilities and worry that they can't cope with various problems they may face in starting a business. The main skills involved in the entrepreneurial process in- 
clude: social skills, marketing skills, development skills, management skills and so on. If there is no targeted study and exercise at ordinary times, it is difficult to achieve it overnight.

\subsection{Lack of Resources}

Entrepreneurial resources mainly include capital, time, talent, market and other aspects [7], among which market resources are particularly lacking. Market resources include commodity purchase channels, sales channels, etc. College students have a narrow contact area. If their family and friends can't provide help, it will be difficult for them to obtain various resources by themselves. A lot of people at the beginning of the business, are resources are very poor. If almost any resources are not available, blind entrepreneurship will be very likely to fail; but it's impossible to have all the resources. In terms of resource availability, generally speaking, two conditions should be met: one is to have the basic resources to enter an industry; the other is to have the differential resources [8].

\subsection{Fear of Financial Losses}

College students do not have any source of income, tuition, living expenses for ordinary families are not a small expenditure. If let parents give money as their own start-up capital, some parents may not support; some families have limited income sources, so taking out a certain amount of start-up capital will increase the burden on the family. It is difficult for college students to obtain funds from other channels, so most of them choose to use their saved pocket money or living expenses as the start-up capital. In this way, if it is funded by the parents, the loss of worry is not easy to explain; if it is your living expenses or pocket money, a loss will also reduce your quality of life.

\subsection{Lack of Instructors}

College entrepreneurship instructors play an important role in the process of innovation and entrepreneurship of college students. However, the proportion of college teachers with entrepreneurial experience or rich theoretical knowledge of entrepreneurship is low, and each teacher's energy is limited, so it is unrealistic to instruct many students at the same time. In addition, students have little contact with entrepreneurship teachers. Most students seek guidance from teachers of their own major or teachers who teach entrepreneurship courses. This may result in that some teachers instruct many students, while some teachers instruct few or even no students. This asymmetry of information is also a reason for the lack of teachers.

\section{College Students Entrepreneurship Guidance and Incentive Measures}

\subsection{Policy Guidance and Increased Publicity}

From the enrollment to the four-year learning process, the school should make 
students and their parents know about the policies and latest developments related to entrepreneurship of the country, provinces and schools through various forms, so as to make students' parents understand and support students' entrepreneurship as much as possible. Make full use of all kinds of network media for publicity, including website, WeChat public account, microblog, live video, etc., to create a campus entrepreneurial atmosphere, so that students can feel the full swing of entrepreneurship. The establishment of business incubation base, from point to area, regular evaluation and exchange; Introducing excellent entrepreneurial cases and sharing experience to stimulate students' passion for entrepreneurship.

\subsection{Conduct Regular Entrepreneurship Training and Carry out the Second Class}

In addition to offering entrepreneurship courses, it can also assist in various forms of entrepreneurship education and training. Entrepreneurship training aims to cultivate college students' entrepreneurial concepts and ideas [9]. Entrepreneurship training can take many forms. First, students can be encouraged to take online entrepreneurship courses. Second, regular free entrepreneurial skills training courses. Third, in the form of the second classroom, teachers lead students to carry out practical activities; Fourth, often invite entrepreneurs into the campus to give theme lectures to students; Fifth, the establishment of a maker studio, students and teachers often hold activities, the collision of ideas.

\subsection{Expand the Team of Entrepreneurship Instructors and Strengthen the Training of Instructors}

After all, only a few college teachers have entrepreneurial experience, and the number of full-time teachers teaching entrepreneurship courses is limited. However, it is not necessary to have entrepreneurial experience and experience to guide students to start a business. As long as students have certain theoretical knowledge and life experience of entrepreneurship, they can also guide students to start a business. Entrepreneurship theory knowledge teachers can be obtained through unified training combined with self-study. In addition, some entrepreneurs can also be hired as part-time instructors. In addition to inviting students to give lectures, students can also consult through the Internet and visit enterprises on the spot. Sometimes practical experience is more important than theoretical knowledge.

\subsection{Develop Standards and Increase Rewards for Teachers and Students}

In order to encourage the enthusiasm of teachers and students to start businesses and participate in entrepreneurship competitions, schools should formulate corresponding reward standards. For example, students can replace the corresponding courses or deduct certain credits for entrepreneurship and competition. Prominent achievements in entrepreneurship should be publicized and re- 
warded; Competitors and winners will be rewarded accordingly. According to the teacher's guidance to students to start businesses or reference competitions, class subsidies will be given. If the students under the guidance take part in competitions and win prizes, certain rewards will also be given accordingly. At present, most colleges and universities focus on rewarding the competition and winning awards, but are not willing to reward the actual entrepreneurial achievements. In fact, a lot of competition scores now increasingly focus on whether there is a real business and the actual operation of the business.

\subsection{The University and College Will Provide Support and Teachers will Take the Lead to Form a Team}

In the early stage of entrepreneurship, students are in lack of space, resources and funds, etc., so schools and colleges should provide support as much as possible, such as providing free space to help students find resources, or even setting up venture funds to provide certain financial support for entrepreneurial students. As for the management risks that students are worried about, after the demonstration and negotiation, part of the fund can be shared by the university, college and teachers. In other words, the fund, teachers and students can jointly invest and become shareholders to set up a company, so as to reduce the financial pressure on students. Another advantage of this is that students who graduate or drop out can find other students to join the team and keep a good project going.

\subsection{Explore New Talent Training Mode in Combination with Entrepreneurship}

The courses and talent training programs of the school are for all students. Although there are some entrepreneurship courses in the school, the class hours are limited and the courses offered are also limited, especially those that are closely combined with various majors. When designing talent training programs and course plans, each school can try to combine entrepreneurship, establish some training programs for new major directions, and explore new talent training models. For example, combining the major of e-commerce with the direction of entrepreneurship, designing the training mode of entrepreneurial talents of e-commerce; Combine business administration major with entrepreneurial direction, design management talent training mode for small and micro enterprises, etc.

\section{Conclusion}

Under the background of slowing down global economic growth and increasing downward pressure on China's economy, the number of newly created jobs in China every year is lower than the number of college graduates, and the employment pressure is increasing [10]. According to the Ministry of Human Resources and Social Security, the number of college graduates across the country is increasing year by year. Affected by the severe employment situation in China, 
more college graduates need to embark on the road of self-employment [11]. In the entrepreneurship education of college students, we should first understand the motivation of college students to start their own businesses and the reasons why they do not want to start their own businesses, and then give targeted guidance and incentives. This paper studies the problems of college students' guidance and incentive mechanism, explore the reasonable way of college students' entrepreneurial guidance, and the effective and feasible incentive mechanism. In order to promote the entrepreneurship of college students, to achieve the goal of entrepreneurship education service. The sample size of the questionnaire survey conducted in this paper is small and the scope is limited. The answers to the same question may vary among college students in different regions and at different levels. In the future, a wider range of surveys and further in-depth studies will be conducted.

\section{Funding}

College level teaching research project of Anhui University of Finance and Economics: Study on Guidance and Incentive Mechanism of Undergraduate Entrepreneurship (ACJYYB2018128).

\section{Conflicts of Interest}

The authors declare no conflicts of interest regarding the publication of this paper.

\section{References}

[1] Li, Y.Q., Bai, X., Mao, Y., et al. (2008) A Review of the Influencing Factors of Entrepreneurial Intention. Journal of Economics, 2, 81-83.

[2] Pan, W.Q. and Yang, L. (2014) A Review on the Influencing Factors of College Students' Entrepreneurial Consciousness. Exploration of Higher Education, 5, 173-177.

[3] Xiang, C. and Lei, J.S. (2011) The Relationship between Entrepreneurship Attitudes and Tendencies of College Students: A Study of Tsinghua University Students. Education Research of Tsinghua University, 10, 116-124.

[4] Ding, M.L. and Ding, S.W. (2011) Entrepreneurial Self-Efficacy, Perception of Behavioral Control and Entrepreneurial Intention of College Students. Statistics and Information Forum, 3, 108-112.

[5] Cao, X. and Tang, Y. (2012) An Empirical Study on the Influencing Factors of University Technology Entrepreneurship Intention. Systems Engineering, 11, 68-76.

[6] Liu, Z. (2013) An Empirical Study on the Structure and Current Situation of College Students' Entrepreneurial Intention. Educational Development Research, 21, 35-40.

[7] Li, M. and Dong, Z.Y. (2014) Research on the Influence of Risk Perception Factors on Entrepreneurial Intention-The Mediating Effect of Perceived Risk and the Moderating Effect of Rule Focusing. Journal of Management Engineering, 3, 26-32, 41 .

[8] Xu, X.Z., Mei, W.H. and Ni, H. (2015) College Students' Entrepreneurship Dilemma and Institutional Innovation. China Higher Education Research, 1, 45-48, 53.

[9] Zhang, H. (2017) Research on Innovation and Entrepreneurship Education in Uni- 
versities: Mechanism, Path and Mode. Journal of National Institute of Education Administration, 10, 28-32.

[10] Li, C.L. (2019) Research on the Incentive Mechanism of College Students' Innovation and Entrepreneurship. China Rural Education, 12, 35-37.

[11] Zhang, Y.H. (2020) Innovation and Entrepreneurship Incentive Mechanism of College Students. Education and occupation, 1, 64-68. 